\section{Intergovernmental Authority on Development}

The Intergovernmental Authority on Development was created on 21 March 1996 and has its origins in the Intergovernmental Authority on Drought and Development, which had been established in 1986. It has three priority areas of co-operation: conflict prevention, management and humanitarian affairs; infrastructure development; food security and environment protection.

Members. Djibouti, Ethiopia, Kenya, Somalia, Sudan, Uganda. Eritrea was formerly a member but withdrew in April 2007.

Headquarters: Ave. Georges Clemenceau, PO Box 2653,

Djibouti, Republic of Djibouti.

Website: http://igad.int

Executive Secretary: Mahboub Maalim (Kenya).

\section{Lake Chad Basin Commission}

Established by a Convention and Statute signed on 22 May 1964 by Cameroon, Chad, Niger and Nigeria, and later by the Central African Republic (Sudan has also been admitted as an observer), to regulate and control utilization of the water and other natural resources in the Basin; to initiate, promote and co-ordinate natural resources development projects and research within the Basin area; and to examine complaints and promote settlement of disputes, with a view to promoting regional co-operation.

In Dec. 1977, at Enugu in Nigeria, the 3rd summit of heads of state of the commission signed the protocol for the Harmonization of the Regulations Relating to Fauna and Flora in member countries, and adopted plans for the multi-donor approach towards major integrated development for the conventional basin. An international campaign to save Lake Chad following a report on the environmental degradation of the conventional basin was launched by heads of state at the 8 th summit of the Commission in Abuja in March 1994. The 10th summit, held in N'Djaména in 2000 , saw agreement on a US $\$ 1 \mathrm{~m}$. inter-basin water transfer project.

The Commission operates an annual budget of $1 \mathrm{bn}$. francs $\mathrm{CFA}$, and receives assistance from various international and donor agencies including the FAO, and UN Development and Environment Programmes.

Official languages: English, French.

Headquarters: BP 727, N’Djaména, Chad.

Executive Secretary: Abdullahi Umar Ganduje (Nigeria).

\section{Niger Basin Authority}

As a result of a special meeting of the Niger River Commission (established in 1964), to discuss the revitalizing and restructuring of the organization to improve its efficiency, the Niger Basin Authority was established in 1980. Its responsibilities cover the harmonization and co-ordination of national development policies; the formulation of the general development policy of the Basin; the elaboration and implementation of an integrated development plan of the Basin; the initiation and monitoring of an orderly and rational regional policy for the utilization of the waters of the Niger River; the design and conduct of studies, researches and surveys; the formulation of plans, the construction, exploitation and maintenance of structure, and the elaboration of projects.

Members. Benin, Burkina Faso, Cameroon, Chad, Côte d'Ivoire, Guinea, Mali, Niger, Nigeria.

Official languages: English, French.

Headquarters: BP 729, Niamey, Niger.

Website: http://www.abn.ne

Executive Secretary: Oyewole Ogunmola (Nigeria).

\section{Southern African Customs Union (SACU)}

Established by the Customs Union Convention between the British Colony of Cape of Good Hope and the Orange Free State Boer Republic in 1889, the Southern African Customs Union was extended in 1910 to include the then Union of South Africa and British High Commission Territories in Africa and remained unchanged after these countries gained independence. South Africa was the dominant member with sole-decision making power over customs and excise policies until the 2002 SACU Agreement which created a permanent Secretariat, a Council of Ministers headed by a minister from one of the member states on a rotational basis, a Customs Union Commission, Technical Liaison Committees, a SACU tribunal and a SACU tariff board.

Members. Botswana, Lesotho, Namibia, South Africa, Swaziland.

Aims. To promote economic development through regional coordination of trade.

Headquarters: Private Bag 13285, Windhoek, Namibia.

Website: http://www.sacu.int

Email: info@sacu.int

Executive Secretary: Tswelopele Cornelia Moremi (Botswana).

\section{Southern African Development Community (SADC)}

The Southern African Development Co-ordination Conference (SADCC), the precursor of the Southern African Development Community (SADC), was formed in Lusaka, Zambia on 1 April 1980, following the adoption of the Lusaka Declaration-Southern Africa: Towards Economic Liberation-by the nine founding member states.

Members. The nine founder member countries were Angola, Botswana, Lesotho, Malawii, Mozambique, Swaziland, Tanzania, Zambia and Zimbabwe. The Democratic Republic of the Congo, Madagascar, Mauritius, Namibia, the Seychelles and South Africa have since joined. The Seychelles left in July 2004 but rejoined in Aug. 2007. As a result there are now 15 members.

Aims and Activities. SADC's Common Agenda includes the following: the promotion of sustainable and equitable economic growth and socio-economic development that will ensure poverty alleviation with the ultimate objective of its eradication; the promotion of common political values, systems and other shared values that are transmitted through institutions that are democratic, legitimate and effective; and the consolidation and maintenance of democracy, peace and security.

In contrast to the country-based co-ordination of sectoral activities and programmes, SADC has now adopted a more 